\title{
The Effect of Good Corporate Governance and Local Culture Values on The Performance of Village Credit Institutions
}

\author{
Ida Ayu Agung Idawati ${ }^{1}$ Ade Ruly Sumartini ${ }^{2}$ Ni Nyoman Suriani ${ }^{3}$ \\ ${ }^{123}$ Management Department, Faculty of Economics and Business, Warmadewa University, Indonesia
}

\begin{abstract}
Lembaga Perkreditan Desa (LPD) is one of the elements of village institutions that performs the functions of traditional village finance to manage the potential of traditional village finance. In Balinese context, LPD is a financial institution adapted to the concept of community in Bali. LPD has the potential and proven capable of advancing the welfare of the village community as well as meeting the needs of the village concerned. The number of LPDs currently in Bali are 1433 LPDs. This study aims to investigate the effect of Good Corporate Governance and Tri Hita Karana as a Balinese local culture toward the performance of Village Credit Institutions (LPDs). The data in this study were collected using questionnaires that were distributed directly to the LPDs in Denpasar area. The technical analysis used in this study is multiple linear regression and $\mathrm{t}(\mathrm{t}$-test) for partial analysis. Based on the results of multiple linear regression analysis, the regression equation $\mathrm{Y}=20,783+0,157 \mathrm{X} 1+0,516 \mathrm{X} 2$ is obtained. The t-test analysis from the regression results shows that Good Corporate Governance and Tri Hita Karana have a significant effect on LPD's performances.
\end{abstract}

Keywords: Good Corporate Governance, Tri Hita Karana, LPD performances

DOI: $10.7176 / \mathrm{EJBM} / 12-24-11$

Publication date:August $31^{\text {st }} 2020$

\section{Introduction}

The Indonesian economy is influenced and supported by various business sectors. One sector that plays a role in the Indonesian economy is the financial sector. The financial sector in general can be divided into 2, Which are bank financial institutions and non-bank financial institutions. Both bank and non-bank financial institutions are expected to be able to carry out their respective roles so as to achieve financial sector goals and can play a role in improving Indonesia's economy. One of the "special" non-bank financial institutions operating in Bali today is the Lembaga Perkreditan Desa (LPD). LPD is one of the elements of village institutions that performs the functions of traditional village finance to manage the potential of traditional village finance. LPD has the potential and proven capable of advancing the welfare of the village community as well as meeting the needs of the village concerned. The LPD is a unique entity because it is based on the local traditions with aspects of the life of village communities in Bali called village manners (Adnyani, 2017).

LPD are non-bank financial institutions that only operate in Bali, because LPDs have concepts adapted to Balinese customs. LPDs as the Balinese financial institution are established in most of the traditional villages / pakraman villages in Bali. The number of LPDs in Bali is currently recorded at 1433 LPDs (kabarnusa.com). This number shows that almost the majority of regions on the island of Bali have LPDs. The concept of LPD that has been adapted to the concept of community in Bali is expected to be able to improve the economic welfare of the Balinese people. The objectives of LPD according to Damayanthi (2011) are: (1) Encouraging economic development of rural communities through effective savings and capital distribution, (2) Eradicating bonded labor, illegal pawns and others, (3) Creating equity and business opportunities for villagers and labor in the rural area, (4) Increasing people's purchasing power and expediting the payment and circulation of money in the village (Sari, 2017). Religious ceremonies are one of the attractions that attract tourists to visit Bali. Bali has and holds many religious ceremonies every year. This of course requires not a small amount of money. The concept of the LPD is expected to be able to alleviate the 'cost burden' that must be borne by the Balinese people for their religious activities.

Performance shows the work of a company. The results of LPD's performance can be assessed from various aspects. One comprehensive performance assessment is a performance score based on Balance Score Card (BSC). According to Campbell (2005), the balanced Score Card can be used as a tool to measure company performance because it provides a comprehensive framework for describing the mission into its intended goals. The BSC consists of four perspectives namely financial perspective, consumer perspective, internal business process perspective and growth and learning perspective. Assessment using these four perspectives is expected to be the basis for strategic improvement, so that ultimately increases the value of the company. Same with the companies, LPDs have the purpose of remembering the value of the company as reflected in the profits generated. 
In general, the principle of good governance, according to the National Committee on Governance (KNKG, 2006), consists of transparency, accountability, responsibility, independence, fairness and equality. Good governance is considered to play a role in encouraging the achievement of company sustainability through management based on the principles of transparency, accountability, responsibility, independence, fairness and equality. The application of good corporate governance can make LPDs more responsible for making decisions because there are clear directions for LPDs so that the impact will increase the value of the LPD itself (Dewi and Putri, 2014). The results of previous studies showed inconsistent results regarding the effect of good corporate governance on performance. Research conducted by Setyawan and Putri (2013), Sandraningsih and Putri (2015), Dewi and Putri (2014) stated that the application of good corporate governance has a positive effect on LPD's performance. Trisnaningsih (2007) and Hidayah (2008) in their research stated that good corporate governance had no effect on performance.

Improving the performance of an LPD is not enough just to apply the principles of GCG, but LPD management ability is also needed to adopt and implement a noble local culture. The local culture in question is local wisdom that is inherent in individual communities and LPD employees in the area (Putri, 2017). The aim of the LPD according to the 2014 parade was to strengthen the resilience of traditional villages in preserving and developing the noble values of Balinese cultures and traditions imbued with Hinduism (Adnyani, 2017). LPD as a financial institution that is close to the Balinese people certainly absorbs noble cultural values that develop in the place where the community operates. These cultural values must also be brought by each individual community as LPD employees who work there. Research by Berggren and Burzynska (2014) discusses about microfinance institutions also include elements of community's social trust. One of the results of his research stated that religion is one of the determinants that influences the performance of microfinance institutions. This is because each place of microfinance institutions has its own social values. The performance of microfinance institutions does not only depend on the conditions of macroeconomics and formal institutions, but also strongly influenced by social values, especially those believed by the local community.

\subsection{Aim of Study}

To provide empirical evidence regarding the effect of good corporate governance and local cultural values (Tri Hita Karana) on the performance of Village Credit Institutions (LPD). Provide an overview of the effect of the influence of Good Corporate Governance and local cultural values (Tri Hita Karana) on the performance of Village Credit Institutions (LPD). LPDs can use the results of this study to follow up on assessing their performance, especially related to governance and local cultural values.

\section{Literature Review and Hypotheses Development}

Corporate governance arises because of the separation between ownership and company control, or better known as agency problems. Corporate governance is a system that regulates and controls companies that are expected to be able to provide and increase company value to shareholders (Herawati, 2009 in Rahnawati, 2011). General Guidelines for Good Corporate Governance Indonesia is issued by the National Committee on Corporate Governance (KNKCG) in 2006, stated that there were five principles of GCG, including: transparency, accountability, responsibility, independence, fairness and equality.

Bali as an island that has strong cultural and religious roots has a variety of local wisdom. One of the local wisdom that is suitable to be applied in the tourism industry is the philosophy of Tri Hita Karana. Tri Hita Karana comes from Sanskrit which means three causes of goodness, well-being or happiness that come from three harmonious relationships, namely: Parahyangan which means a harmonious relationship between humans and God Pawongan which means a harmonious relationship among human beings and Palemahan which means harmonization between humans and their natural environment (Dalem 2007).

Balance score cards are an example of a performance measurement system. According to proponents of this approach, business units must be given goals and measured from the following four perspectives:

a. Finance (for example: profit margin, return on assets, cash flow).

b. Customers (for example: market share, customer satisfaction index).

c. Internal Business (for example: employee retention, reduction in cycle time).

d. Innovation and learning (for example: the percentage of sales of new products). 
Balance score cards maintain a balance between different strategic measures in an effort to achieve alignment of ideals thereby encouraging employees to act in the best interests of the organization. This is a tool that helps the company to stay focused, improve communication, set organizational goals and provide feedback on strategies (Kopecka, 2015).

Corporate governance is a set of regulations that establish relationships between stakeholders, administrators, creditors, government, employees and other internal and external stakeholders. Badera (2008), Rany and Yasa (2014), Dewi and Putri (2014) and Kusumawati and Bambang (2005) has a research results that show GCG (Good Corporate Governance) has a positive effect on company performance.

$\mathrm{H}_{1}$ : Good corporate governance has a positive effect on the performance of Village Credit Institutions.

LPD in Bali is one of the financial institutions that provide services in the banking sector to the people in the Balinese Pakraman village, from which the LPD absorbs local culture that contains noble values (THK culture) that can support LPD operations. In addition, THK's culture will be unconsciously carried by employees who work in the LPD to their work environment. Badera (2006) examined the influence of Good corporate governance and organizational culture on organizational performance. The results of his research found that GCG and organizational culture had a significantly positive effect on organizational performance. The results of Sudarwan's research (1995) found that national culture reflected in the organization had an effect on accounting values. Adiputra (2014) found that there was an effect of task complexity on internal auditor performance and THK moderation. Surya (2014) found that THK culture can improve company performance.

$\mathrm{H}_{2}$ : The local cultural value of 'Tri Hita Karana' has a positive effect on LPD's performance

\section{Research Methodology}

\subsection{Data Source and Sample}

The population of this study is the LPDs which are operated all around Bali. The sample is selected using purposive sampling method based on several criteria, namely:

a Districts / cities that has an LPD

b District / cities that has the lowest number of LPDs with the least healthy or bankrupt conditions.

c District / cities whose local culture has been influenced by other cultures.

Based on these criteria, the sample in this study is LPDs in Denpasar City.

\subsection{Data Collection Technique}

This study uses questionnaire data collection techniques. The questionnaire data collection technique is done by giving a list of questions and statements according to the indicators that have been compiled and distributed in the internal work environment of the LPD. Before administering the questionnaire, the researcher will explain in advance about the important indicators in the questionnaire. Data will be obtained from the results of filling out the internal questionnaires and LPD customers in Denpasar City. 


\subsection{Research Model}

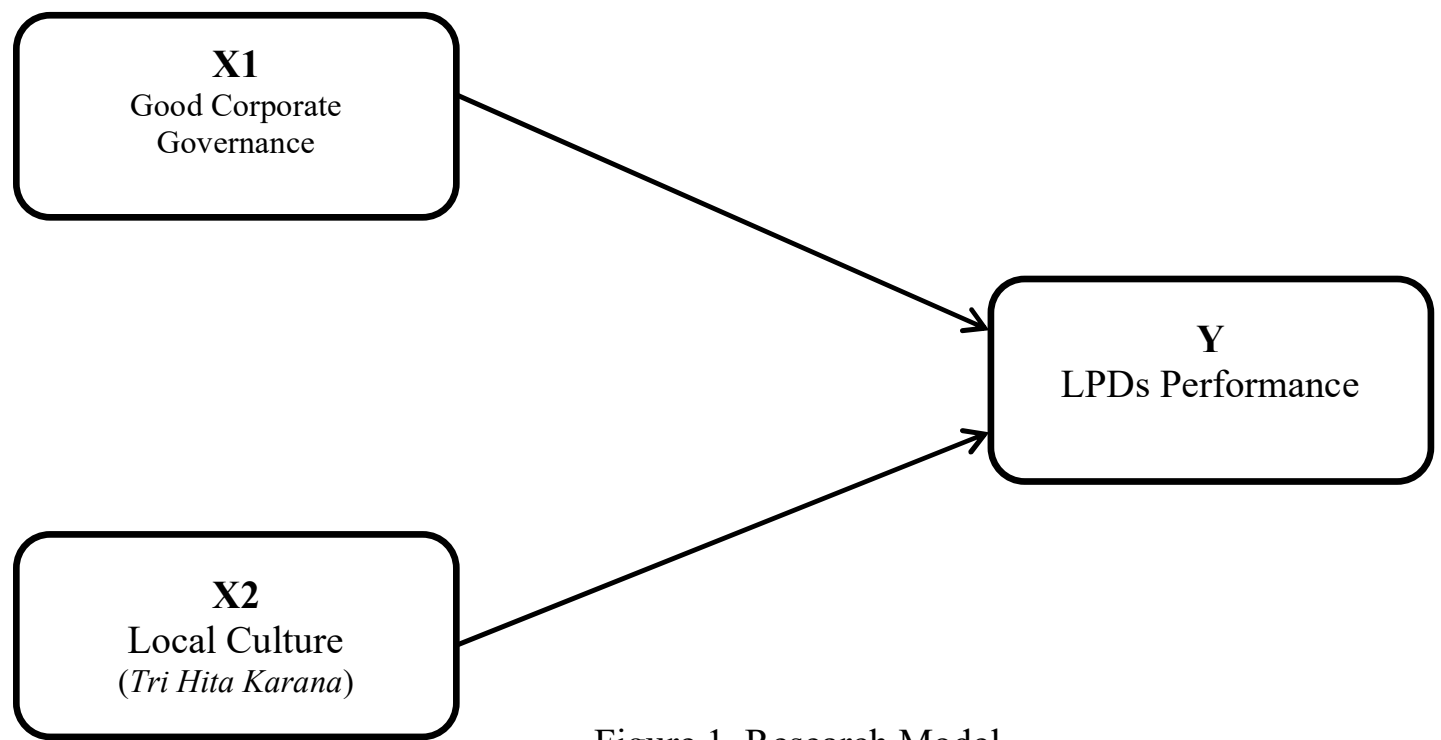

Figure 1. Research Model

\subsection{Data Analysis}

The research model was tested using multiple linear regression analysis which is assisted by the SPSS program. Testing the validity and reliability of research instruments are very important to do to obtain valid and reliable research results. The provisions of an instrument are said to be valid if it has a Pearson Product Moment correlation coefficient (r) $>0.3$ with alpha of 0.05 (Sugiyono, 2014: 172). An instrument is said to be reliable or reliable, if it has an alpha coefficient $(\alpha)$ greater than 0.60 (Sugiyono, 2014: 172).

Before the regression model is done to test the hypothesis, of course the model is free from the classical assumption test. The normality test aims to test whether in the regression model, the disturbing or residual variables have a normal distribution. Multicollinearity test aims to test whether the regression model found a correlation between independent variables. Heteroscedasticity test aims to test whether the regression model occurs.

This multiple linear regression model is used to determine the effect of the dependent variable with two or more independent variables.

The regression equation used is:

$\mathrm{Y}=\mathrm{a}+\mathrm{b} 1 \mathrm{X} 1+\mathrm{b} 2 \mathrm{X} 2+\mathrm{e}$

Notation:

$\mathrm{Y}=$ LPD's performance

$\mathrm{X} 1=$ Good Corporate Governance

$\mathrm{X} 2=$ Cultural Value; Tri Hita Karana

$\mathrm{b} 1=$ Regression coefficient of Good Corporate Governance (X1)

b2 = Regression coefficient of Cultural Value; Tri Hita Karana (X2)

$\mathrm{e}=$ Error

Table 1. Regression Result

\begin{tabular}{|l|r|r|r|}
\hline & \multicolumn{1}{|c|}{ Beta } & \multicolumn{1}{c|}{ t } & \multicolumn{1}{c|}{ Sig. } \\
\hline Constant & 20,873 & & \\
\hline GCG & 0,157 & 2,468 & 0,016 \\
\hline THK & 0,516 & 10,085 & 0,000 \\
\hline
\end{tabular}

Based on the table above a multiple regression equation is as follows: $\mathrm{Y}=20,783+0,157 \mathrm{X} 1+0,516 \mathrm{X} 2+\mathrm{e}$ 
Testing of adjusted R2 $=0$ is used to measure the proportion or percentage of independent variable contributions which are examined against variations in the ups and downs of the dependent variable. Adjusted R2 ranges from 0 to 1 . This means that if the adjusted $\mathrm{R} 2=0$, it shows that there is no influence between the independent variables on the dependent variable, if the adjusted R2 value is getting closer to 1, it indicates a strong influence of the independent variable on the dependent variable and if the adjusted R2 approaches 0 , it can be said that the influence of the independent variable on the dependent variable is low.

Hypothesis testing is done by partial test, namely to find out the relationship of each independent variable to the dependent variable using the t-test. Testing of Partial Regression Coefficients (t-Test). The statistical t-test is referred to as a significant individual test. This test shows how far the influence of the independent variable (independent) partially on the dependent variable (dependent). The form of testing is: $\mathrm{H}_{0}: \mathrm{b} 1=0$, meaning that an independent variable partially does not affect the dependent variable. $\mathrm{H}_{0}: \mathrm{b} 1 \neq 0$ means that an independent variable partially influences the dependent variable. Decision criteria: If the probability is $\leq 0.05$ then $\mathrm{H}_{\mathrm{a}}$ is accepted or $\mathrm{H}_{0}$ is rejected. If the probability is $>0.05 \mathrm{H}_{0}$ is not rejected.

\section{Results and Discussions}

Validity Test Results show that all items contained in the questionnaire can be said to be valid because the correlation coefficient is greater than the $\mathrm{r}$ table value $=0.3$. Thus all research items used are valid. In addition to validity testing, the research instrument must meet the reliability test. According to Nunnally and Ghozali (2001: 133) states that the variable is said to be reliable if the Cronbach alpha value $>0.60$.

Table 2 Reliability Test Result

\begin{tabular}{|l|l|l|l|}
\hline NO & Question & $\begin{array}{l}\text { Correlation } \\
\text { Coefficien }\end{array}$ & Remark \\
\hline 1 & GCG & 0,886 & Reliable \\
\hline 2 & Tri Hita Karana & 0,926 & Reliable \\
\hline 3 & LPD's performance & 0,881 & Reliable \\
\hline
\end{tabular}

Source: Data processed, 2018

All instruments have a Cronbach alpha value of more than 0.6 so it can be concluded that all of these variables are reliable.

Table 3 Multicollinearity Test Results

\begin{tabular}{|c|c|c|}
\hline Variable & Tolerance & VIF \\
\hline GCG & 0.998 & 1.002 \\
\hline THK & 0.998 & 1.002 \\
\hline
\end{tabular}

Based on the table above, all variables have Tolerance values of more than 0.10 and VIF of less than 10 . These results indicate that in the regression model there is no multicollinearity between variables.

Table 4 Heteroscedasticity Test Results

\begin{tabular}{|c|c|}
\hline Variable & Heteroscedasticity Sig. \\
\hline GCG & 0,799 \\
\hline THK & 0,964 \\
\hline
\end{tabular}

The test results show that each independent variable, which are good corporate governance $=0.799$ and Tri Hita Karana variable $=0.964$ have a significance level above 0.05 . Then it can be concluded that there are no symptoms of heteroscedasticity in the regression model used.

The regression equation $\mathrm{Y}=20,783+0,157 \mathrm{X} 1+0,516 \mathrm{X} 2+$ e can be described as follows:

$\alpha=20,783$ (Constants) 
When good Corporate Governance (X1) and Tri Hita Karana (X2) are constant or 0 then Y (LPD's performance) has a value of 20,783 .

\section{b1 $=0.157$ (Coefficient of Regression X1)}

If the variable Good Corporate Governance (X1) increases by 1 unit, it impacts on Y (LPD's performance) which has an increase of 0.157 assuming other variables are constant.

b2 = 0.516 (Coefficient of Regression X2) explains;

If the Tri Hita Karana variable (X2) increases by 1 unit then Y (LPD's performance) which increases by 0.516 assuming other variables are constants.

The equation of multiple linear regression analysis above shows that the direction of influence of each independent variable on the dependent variable indicated by the regression coefficients of each independent variable. The coefficients of both independent variables have a positive sign, which means that these variables have a direct influence on the performance of the LPD's performance.

This coefficient of determination is used to measure how much the variation ability of the independent variables in explaining the variation of the dependent variable. Adjusted R square coefficient value as in table 5:

\section{Table 5 Model Summary}

\begin{tabular}{|c|r|r|r|}
\hline Model & R & R Square & \multicolumn{1}{|c|}{$\begin{array}{c}\text { Adjusted R } \\
\text { Square }\end{array}$} \\
\hline 1 & 0,798 & 0,637 & 0,625 \\
\hline
\end{tabular}

The results of regression calculations shows that the adjusted $\mathrm{R}$ square value is 0.637 . This means that 63.7 percent of the variation in LPD's performance variables can be explained by the Good Corporate Governance (X1) and Tri Hita Karana (X2), while the remaining 36.3 percent is explained by other variables not included in this research model.

a. Effect of Good Corporate Governance (X1) on LPD's performance (Y)

The significance value of the GCG variable is $0.016<0.05$, means that the GCG variable has a positive effect on LPD's performance in Denpasar City. The results of this study support previous findings from the research of Badera (2008), Rany and Yasa (2014), Suparsabawa and Kustina (2018) and Emile et al (2014) which explain that the practice of Good Corporate Governance is seen as a very important contributor for a company because it can reduce risk, attract investors' attention and improve company performance.

b. Effect of Tri Hita Karana (X2) on LPD's performance (Y)

The significance value of the THK variable is $0,000<0,05$, which means that the THK variable has a positive effect on LPD's performance. This result supports the research of Badera (2008) and Riana (2010) and Surya (2014), Dwija Putri, et al. who states that THK has an effect on LPD's performance.

\section{CONCLUSION}

1. Good Corporate Governance has a positive effect on LPD's performance in Denpasar City. This shows that the better the application of the principles of Good Corporate Governance, the LPD's performance will also increase.

2. The value of local culture reflected in Tri Hita Karana (THK) has a positive effect on LPD's performance in Denpasar City. This means that the deeper members of the organization absorb and implement the Tri Hita Karana culture, the more LPD's performance will increase.

\section{References}

Adiputra, I Made Pradana. (2014). Budaya Tri Hita Karana Sebagai Pemoderasi Pengaruh Kompleksitas Tugas terhadap Kinerja Internal Auditor (Studi Pada Kantor Inspektorat di Provinsi Bali). Jurnal Dinamika Akuntansi, 6(2), 191-206 
Adnyani, Ketut Sonya. 2017. Praktik Tata Kelola dalam Perspektif Nilai Budaya Lokal Pada Lembaga Perkreditan Desa. Tesis. Universitas Gadjah Mada. Tidak Dipublikasikan.

Badera, I., N. (2008). Pengaruh Kesesuaian Hubungan Corporate Governance dengan Hubungan Budaya Korporasi terhadap Kinerja Perusahaan, Disertasi. Universitas Gadjah Mada

Berggren, Olle dan Katarzyna Burzynska. 2014. The Impact of Social Beliefs on Microfinance Performance. Working Paper, Knut Wicksell Centre for Financial Studies Lund University.

Campbell, Dennis, Datar, Srikunt, Kulp, Cohen, Susan and Narayana, V.G. 2005. Using The Balanced Scorecard as a Control System for Monitoring and Resiving Coorporate Strategy. www.ssrn.com

Dalem, A.A.G.R. (2007) "Filosofi Tri Hita Karana dan Implementasinya dalam Industri Pariwisata," In Kearifan Lokal dalam Pengelolaan Lingkungan Hidup (Local Wishdom/Possitive Local Values or Local Genious in Environmental Management), (ed.) A. A. G. Raka Dalem, I N. Wardi, I W. Suarna and I W. Sandi Adnyana. Denpasar: UPT Penerbit Unud and PPLH Unud, 81-94.

Damayanthi, I.G. 2011. Pengungkapan Tanggung Jawab Sosial Lembaga Perkreditan Desa(LPD) Berdasarkan Filosofi Tri Hita Karana [Online]. Tersedia di: https:/ojs.unud.ac.id/index.php/jiab/article/view/2656 [diakses pada tanggal 17 Maret 2018].

Dewi, Kadek Krismaya dan I G A M Asri Dwija Putri. 2014. Pengaruh Penerapan Prinsip-prinsip GCG pad Kinerja Keuangan Lembaga Perkreditan Desa Kabupaten Gianyar, Provinsi Bali. Jurnal Akuntansi Universitas Udayana. Vol 8 No 1. Hal: 70-82

Emile, Rimon, Aiman Ragab and Sandy Kyaw. 2014. The Effect of Corporate Govermamce on Firm Performance, Evidence from Egypt. Asian Aconomic and Financial Review. 4(12), 1865- 1877.

Hidayah, Erna. 2008. Pengaruh Kualitas Pengungkapan Informasi terhadap Hubungan antara Penerapan Corporate Governance dengan Kinerja Perusahaan di Bursa Efek Jakarta.

Komite Nasional Kebijakan Governnace. 2006. Asas Good Corporate Governance. http://www.bapepam.go.id/. Diunduh 17 Maret 2018.

Kopecka, Nattarinee. 2015. The Balanced Scorecard Implementation, Integrated Approach and The Quality of Its Measuremet. Procedia Economics and Finance 25 (2015). hal: 59-69

Kusumawati, Dwi Novi dan Bambang Riyanto LS. 2005. Corporate Governance dan Kinerja:Analisis Compliance Reporting dan Struktur Dewan Terhadap Kinerja. Simposium Nasional Akuntansi (SNA) VIII Solo.

Pertiwi, Diah Ayu (2010). “Analisis Pengaruh Earning Management terhadap Nilai Perusahaan dengan Peranan Praktik Corporate Governance sebagai Moderating Variabel pada Perusahaan yang terdaftar di Bursa Efek Indonesia Periode 2005-2008.” Skripsi, Fakultas Ekonomi Universitas Diponegoro, Semarang.

Putri, I.G.A.M Asri Dwija; I.G.K.A Ulupui dan Ni Gusti Putu Wirawati. 2017. Pengaruh Good Corporate Governance dan Budaya Tri Hita Karana Pada Kinerja BPR. Jurnal Ilmiah AKuntansi dan Bisnis, Vol 12, No 1. Hal: 17-24

Rany, Y. Y., \& Yasa, G. W. (2012). Pengaruh Penerapan Corporate Governance Terhadap Return On Equity (ROE). EJurnal Akuntansi, 1(1). Riana, I Gede. 2010. Dampak Penerapan Budaya Tri Hita Karana terhadap Orientasi Kewirausahaan dan Orientasi Pasar serta Konsekwensinya pada Kinerja Usaha dengan Moderator Pembelajaran

Ridwan,2003. Skala Pengukuran Variabel-variabel Penelitian, Alfabeta: Bandung.

Sandraningsih, Ni Kadek Budi dan I G A M Asri Dwijaputri. 2015. Pengaruh PrinsipPrinsip Good Corporate Governance pada Kinerja Keuangan Lembaga Perkreditan Desa Kecamatan Abiansemal. E-Jurnal Akuntansi Universitas Udayana,11(3): 878-893. 
Sari, Putu Yunita; Anantawikrama Tungga Atmadja dan Gede Adi Yuniarta. 2017. Analisis Pengendalian Kredit Macet Dengan Implementasi Konsep Tat Twam Asi Pada Lembaga Perkreditan Desa Tigawasa. Jurnal Akuntansi. Vol 8, No 2. Hal:1-11

Setyawan, Komang Meitradi dan I Gusti Ayu Made Asri Dwija Putri. 2013. Pengaruh Good Corporate Governance terhadap Kinerja Keuangan Lembaga Perkreditan Desa di Kecamatan Mengwi Kabupaten Badung.

Sudarwan. (1995). The Dynamyc Relationship Between Culture and Accounting: an Empirical Examination of The Indonesian Setting, Disertation. Case Western Reserve University

Suparsabawa, I.N Raditya dan Ketut Tanti Kustina. 2018. Pengaruh Penerapan Good Corporate Governance dan Budaya Tri Hita Karana Terhadap Kinerja Manajerial Lembaga Perkreditan Desa (LPD). Jurnal Riset Akuntansi. Vol 8, No 1, hal: 58-68

Surya, Ida Bagus Ketut. 2014. Pengaruh Budaya Tri Hita Karana terhadap Kinerja Perusahaan dengan Mediasi Kepemimpinan dan Komitmen Organisasional. Disertasi. Universitas Brawijaya.

Trisnaningsih, Sri. 2007. Independensi Auditor Dan Komitmen Organisasi sebagai Mediasi Pengaruh Pemahaman Good Governance, Gaya Kepemimpinan dan Budaya Organisasi terhadap Kinerja Auditor. Simposium Nasional Akuntansi X. Makassar, 26-28 Juli 2007. 